\title{
Establishment and survival of Illinois bundleflower inter- seeded into an established kleingrass pasture
}

\author{
R.L. DOVEL, M.A. HUSSEY, AND E.C. HOLT
}

\section{Abstract}

The introduction of perennial legumes into warm-season grass pastures has been shown to improve both forage quality and animal performance. Illinois bundleflower (Desmanthus illinoensis (Michs.) MacM.) appears to have potential for pasture and range interseeding. This study investigated establishment methods and the competitive ability and longevity of this species when interseeded into kleingrass (Panicum coloratum L.) swards. Sabine Illinois bundleflower was drilled or broadcast into a mature kleingrass pasture either intact or suppressed by disking, paraquat (1-dimethyl-4-4 dipyridinium dichloride), or mefluidide ( $\mathrm{N}-[2,4$ dimethyl-5 (trifuromethyl) sulfonyl)-amino)phenyl)]acetamide). Seed was sown in broadcast plots at $6.8 \mathrm{~kg}$ PLS/ha compared to $3.4 \mathrm{~kg} \mathrm{PLS} / \mathrm{ha}$ in drilled plots.

Establishment data were only collected for 1 year. The establishment year had a wetter than normal spring. Treatment effects on legume establishment could differ substantially from those found in this study in drier years. Both paraquat and disking treatments resulted in good establishment of the legume (greater than 10 seedlings $\mathrm{m}^{-2}$ in the establishment year). With the exception of disked plots, broadcasting at twice the rate of drilled plots resulted in similar seedling legume densities between the 2 seeding methods. Illinois bundleflower proved to be quite competitive under the conditions of this study. The legume component increased from $14 \%$ in the establishment year to $52 \%$ by the third year after establishment. Individual Illinois bundleflower plants survived for the $\mathbf{4}$ years of the study. Interseeding increased total plot yield in the second, third, and fourth years after establishment. Interseeded plots produced more biomass than noninterseeded plots 1, 2, and 3 years after interseeding.

Keywords: Illinois bundleflower, Desmanthus illinoensis, interseeding

The inclusion of legumes in warm-season pastures has been shown to improve the nutritive value of the animal diet and thus animal performance (Whiteman 1980). Interseeding legumes into warm-season grass pastures may also increase total forage production (Cook and Dolby 1981). Extensive introduction and evaluation programs in Texas have identified several legume species, including Illinois bundleflower, which appear to have potential for pasture and range seeding (Holt et al. 1980, Holt and Allison 1981).

Illinois bundleflower (Desmanthus illinoensis (Michs.) MacM.), is the most widely distributed Desmanthus species in the United States. It is a perennial prairie forb ranging from South Dakota and Minnesota to Florida and from Colorado to the Carolinas (Latting 1961, Wasser 1982). Sabine Illinois bundleflower was recently released by the USDA Soil Conservation Service in cooperation with the Texas Parks and Wildlife Department and the Texas Agricultural Experiment Station (Anonymous 1984). It is recommended as a useful range and pasture legume, for wildlife food, and for reclaiming surface mined areas. Sabine is adapted to

\footnotetext{
Authors are former graduate research assistant, (presently assistant professor, Oregon State University, Klamath Falls); assistant professor, and professor emeritus, Texas Agricultural Experiment Station, Texas A\&M University, College Station 77843.

Manuscript accepted 27 April 1989.
}

areas from southern Texas to northern Oklahoma receiving over $38 \mathrm{~cm}$ annual precipitation; however, it has also grown well on selected sites in Mississippi.

Although Illinois bundleflower is reported to be long lived (Latting 1961), recent observations indicate that on some sites the species may be relatively short lived (Holt 1984). The species is reported to be adequately competitive (Wasser 1982). However, the competitive ability of seedlings and their ability to perennate in an established grass sward has not been documented.

The effect of sowing method on Illinois bundleflower establishment has not been documented. However, temperate forage legumes have established by surface sowing where soil moisture for seed germination and seedling growth were adequate (Cullen 1966, McWilliam and Dowling 1970, Campbell and Swain 1973). Sirato (Macroptilium atropurpureum D.C.) and several Stylosanthus species have also established well when broadcast into a warmseason grass pasture (Cook and Dolby 1981, Mott et al. 1976). Drilling provides better seed-to-soil contact and places the seed deeper in the soil than broadcast seeding (Welch and Haferkamp 1980). However, many range and pasture conditions are not amenable to drill seeding.

Reduction of competition from established grass plants is often critical for good seedling establishment and growth of interseeded forage legumes (Cullen 1966, Groya and Sheaffer 1981, Taylor et al. 1969). Herbicides such as paraquat (1-dimethyl-4-4 dipyridinium dichloride) and glyphosate ( $\mathrm{N}$-(phosphonomethyl) glycine) have been used to suppress grass growth and improve establishment of interseeded legumes (Kunelius et al. 1982, Olsen et al. 1981). Reduction of top growth of tall fescue by mufluidide ( $N-[2,4$ dimethyl-5 (trifuromethyl)sulfonyl)-amino)phenyl)]acetamide) has been reported by Watschke (1979) and Elkins and Suttner (1974). It has been used as a grass suppressant while interseeding forage legumes into a tall fescue sward (Olsen et al. 1981).

Kleingrass (Panicum coloratum L.) is an erect warm-season perennial bunchgrass that has proven to be compatible with warmseason legumes (Siewerdt and Holt 1974). It is currently used in improved pastures and rangeland mixtures throughout SouthCentral Texas. This species, while not a native to the U.S., has growth characteristics similar to those of many range grasses and would be an acceptable companion plant to test the competitiveness of Illinois bundleflower seedlings in a warm-season grass sward.

The objectives of this study were to evaluate the effectiveness of several grass suppression treatments and 2 sowing methods on the establishment of Illinois bundleflower in a kleingrass sward and to quantify its competitiveness and longevity in a grass-legume mixture.

\section{Materials and Methods}

Sabine Illinois bundleflower was interseeded into a mature kleingrass pasture located $2 \mathrm{~km}$ west of College Station, Texas. The soil at the site had a $\mathrm{pH}$ of 6.5 and was characterized as Westwood silt loam (Fluventic Ustochrept). Fertilizer had not been applied to the pasture for several years. Total soil $\mathrm{N}$ was low, 
while levels of extractable $P$ and exchangeable $K$ were high (105 and $594 \mathrm{mg} \mathrm{kg}^{-1}$, respectively). The average annual precipitation of the area is $88 \mathrm{~cm}$, with peak rainfall occurring in May and September.

The experiment was arranged in a randomized complete block design with 3 replications. Two seeding methods (drilled or broadcast) and 4 grass suppression treatments (control, disking, paraquat, and mefluidide) were employed for a total of 8 grass suppression-sowing method combinations. Noninterseeded plots were included in each replication to evaluate the influence of legume interseeding on grass yield and total plot yield.

Two weeks prior to interseeding, the kleingrass was cut to a height of $5 \mathrm{~cm}$ and the forage removed from the plots. Chemical grass suppression treatments were applied 1 week after clipping and included paraquat at $1 \mathrm{~kg}$ active ingredient (a.i.) $\mathrm{ha}^{-1}$ and mefluidide at $1.44 \mathrm{~kg}$ (a.i) $\mathrm{ha}^{-1}$. Plots that received the mechanical grass suppression treatment were lightly disked on the day prior to planting.

Illinois bundleflower seeds were inoculated and planted on 16 May 1983, into $2.5 \times 6-\mathrm{m}$ plots. Seeds were planted to a depth of 2 $\mathrm{cm}$ at a rate of $3.4 \mathrm{~kg}$ pure live seed (PLS) $\mathrm{ha}^{-1}$ using a pasture drill as recommended by Wasser (1982). Seeds were broadcast at $6.8 \mathrm{~kg}$ PLS ha ${ }^{-1}$ and plots were raked lightly following planting to simulate a light harrowing or chaining (Welch and Haferkamp 1981).

Weather data, including maximum and minimum daily temperature, rainfall and pan evaporation, were collected from a site approximately $100 \mathrm{~m}$ from the plots throughout the study.

The density of seedling and perennial lllinois bundleflower plants, the species composition of the sward, and the spring and early summer yield of the plots were determined each year for 4 years. Due to the differences in seeding rate utilized in the 2 seeding methods, effectiveness of the various sowing method-grass suppression combinations was compared using percent establishment (PE). Percent establishment was obtained by dividing the established plants per $\mathrm{m}^{2}$ by the number of pure live seed planted per $\mathrm{m}^{2}$ and multiplying by 100 . Species composition of the sward was determined on a dry weight basis from a $1-\mathrm{m}^{2}$ sub-sample. Total yield was determined by harvesting $5.6 \mathrm{~m}^{2}$ from each plot with a flail type mower. The harvests were made when the Illinois bundleflower was approximately $25 \%$ seed set to avoid leaf drop. Plots were harvested in early August in 1983 and in mid-July the following years. The densities of seedling and perennial Illinois bundleflower were determined by counting the number of perennating and seedling plants within $10 \mathrm{~cm}$ of a line transecting each plot at $30^{\circ}$ angle to the rows. The same line was used in each plot throughout the study for legume density determination. This allowed estimates of legume survival and longevity within each plot. Counts were taken approximately 2 weeks after each harvest. Plants germinating in the spring were called seedlings, while any legume plant surviving at least 1 winter was considered to be a perennial plant.

Significance $(P<0.05)$ of main effects and interactions was determined by analysis variance (Snedecor and Cochran 1980). Treatment means were separated by the Least Significant Difference (LSD) method $(P<0.05)$. All percentage data were transformed prior to analysis using the arc-sine square root transformation.

\section{Results and Discussion}

\section{Legume Establishment and Density}

Conditions for Illinois bundleflower establishment were very favorable in 1983 due to higher than usual rainfall. Following planting, rainfall exceeded pan evaporation for 3 consecutive weeks. This allowed ample time for the strongly tap-rooted legume to reach lower levels in the soil profile. Weather data collected for the region from 1951 to 1980 shows that on average pan evaporation exceeds rainfall by 1.3 inches during that same period. Results from a similar study in a dry or average year could be quite different than those found in this study.

Both seeding method and grass suppression treatment affected PE. Drilling resulted in higher PE than the broadcast treatment. Disking was the most effective grass suppression treatment resulting in 42\% emergence. Paraquat application also resulted in seedling emergence values that were significantly higher than the control by 30 and $16 \%$, respectively). Mefluidide, with only $5 \%$ emergence, was the only grass suppression treatment that had a lower PE than the control.

There was a significant seeding method by grass suppression treatment interaction. Broadcast application of seed resulted in significantly lower PE than drilling in control and paraquat plots. However, there was no difference in PE between the 2 sowing methods in plots receiving the disking or mefluidide treatments (Table 1). Disking increased establishment of broadcast more than that of drilled seed (Table 1). The efficiency of establishment, as

Table 1. Influence of sowing method and kleingrass grass suppression treatment on density and seedling survival of Illinois bundleflower in Texas.

\begin{tabular}{|c|c|c|c|c|c|}
\hline $\begin{array}{l}\text { Sowing } \\
\text { method }\end{array}$ & $\begin{array}{c}\text { Grass } \\
\text { suppression } \\
\text { treatment }\end{array}$ & $\begin{array}{c}\text { Percent } \\
\text { establish- } \\
\text { ment } \\
(\%)\end{array}$ & $\begin{array}{c}\text { Legume } \\
\text { seedling } \\
\text { denisty } \\
1983^{1} \\
\left(\# \mathrm{~m}^{-2}\right)\end{array}$ & $\begin{array}{l}\text { Perennial } \\
\text { legume } \\
\text { density } \\
1984^{\prime} \\
(\%)\end{array}$ & $\begin{array}{l}\text { Seedling } \\
\text { survival }\end{array}$ \\
\hline Broadcast & $\begin{array}{c}\text { None } \\
\text { Mefluidide } \\
\text { Paraquat } \\
\text { Disk }\end{array}$ & $\begin{array}{r}13 \\
6 \\
20 \\
40\end{array}$ & $\begin{array}{r}7.0 \\
3.0 \\
10.7 \\
20.8\end{array}$ & $\begin{array}{l}3.5 \\
1.7 \\
4.0 \\
8.0\end{array}$ & $\begin{array}{l}50 \\
47 \\
37 \\
38\end{array}$ \\
\hline Drill & $\begin{array}{c}\text { None } \\
\text { Mefluidide } \\
\text { Paraquat } \\
\text { Disk }\end{array}$ & $\begin{array}{r}20 \\
4 \\
40 \\
44\end{array}$ & $\begin{array}{r}5.5 \\
1.3 \\
10.8 \\
11.5\end{array}$ & $\begin{array}{l}2.7 \\
0.7 \\
5.2 \\
3.5\end{array}$ & $\begin{array}{l}49 \\
54 \\
48 \\
30\end{array}$ \\
\hline & $\mathrm{LSD}^{2}$ & 5 & 3.7 & 1.9 & 25 \\
\hline
\end{tabular}

1 Seedlings $\mathrm{m}^{-2}$

${ }^{2} \mathrm{LSD}$ for separation of treatment combination means $(P<0.05)$.

assessed by PE, of the broadcast-disk, drill-Paraquat, and drilldisk treatment combinations was equivalent. The selection of the appropriate treatment combination from among these 3 would be dependent on factors other than the efficiency of legume establishment, such as logistical and/or financial constraints.

Plots receiving the broadcast-disk treatment combination had higher seedling legume densities in the establishment year than disked plots which were drilled. Since PE was similar between the broadcast-disk, drill-Paraquat, and drill-disk treatment combinations, doubling the seeding rate in the broadcast treatment resulted in seedling legume densities twice that in the latter 2 treatment combinations (Table 1). With the exception of the disked plots, broadcasting at twice the seeding rate of drilled plots resulted in similar seedling legume densities between the 2 seeding methods (Table 1).

Increasing the seeding rate of the broadcast treatment may be an affordable sowing method alternative compared to drilling for range interseeding of Illinois bundleflower. Broadcast seeding also allows interseeding of range legumes in areas where drilling is not possible and over a more extensive area than is feasib!e with drilling.

Both grass suppression treatments (disking and paraquat) produced significantly higher seedling densities in the establishment year than plots where grass was not suppressed (Table 1). Although disking resulted in higher seedling densities, it is also the more 
energy-intensive grass suppression method. Paraquat provided grass suppression that resulted in similar seedling legume densities to disking in drilled plots and adequate legume establishment in broadcast plots. Mefluidide was not a satisfactory grass suppression treatment in establishing Illinois bundleflower in kleingrass. Mefluidide application resulted in significantly lower seedling legume densities than found in the control plots. These results are similar to those of Olsen et al. (1981), who found that mefluidide applied at $1.8 \mathrm{~kg}$ a.i. $\mathrm{ha}^{-1}$ reduced red clover establishment although the $0.9 \mathrm{~kg}$ a.i. ha $^{-1}$ rate resulted in similar seedling numbers as the control.

The mechanism for reduction in stand establishment attributed to mefluidide is unknown. It may be that mefluidide had a phytotoxic effect on the legume; however, mefluidide application may also have altered the spatial relationship between the 2 species. Kleingrass is an upright bunchgrass which should permit light to penetrate the canopy and allow a C-3 plant, such as Illinois bundleflower, to grow. However, mefluidide has been shown to produce a shorter, leafier, more prostrate growth habit in forage grasses (Gerrish and Dougherty 1983). This could cause more direct competition between the 2 species.

There was no significant treatment effect observed for the number of seedling plants $\mathrm{m}^{-2}$ after the first year. The density of Illinois bundleflower seedlings in the plots was higher during the 3 years following establishment than in the establishment year. The density of seedling plants averaged across all treatments was 7.3, $15.2,22.1$, and 12.4 seedlings $\mathrm{m}^{-2}$ in 1983 to 1986 , respectively. This is probably due to the production of large amounts of seed by this species. Illinois bundleflower has been reported to produce an average of $1,038 \mathrm{~kg}$ of seed $\mathrm{ha}^{-1}$ year $^{-1}$ over a 9-year period at the Soil Conservation Service Plant Materials Center in Knox City, Texas (Anonymous 1984). The rapid spread of Illinois bundleflower by seed dispersal indicates that it may be possible to plant this legume in strips and, with proper management, the plant could spread into unseeded areas.

The density of Illinois bundleflower plants which were established in 1983 and survived to 1984 (perennial plants) followed the same trend as seedling density in the establishment year. There was no effect of sowing method or grass suppression on percent seedling survival (Table 1). Perennial Illinois bundleflower density increased throughout the study rising from an average of 3.1 plants $\mathrm{m}^{-2}$ in 1984 to 8.7 plants $\mathrm{m}^{-2}$ in 1986 . Roughly $42 \%$ of the first year seedlings survived into 1984 while only $25 \%$ of the 1984 volunteer seedlings perennated and $8 \%$ of the 1985 volunteer seedlings survived until the next year. This is likely due to intraspecific competition as Illinois bundleflower comprised an increasingly larger portion of the sward. Individual plants were observed to survive for

Table 2. Yield components in 1983 of Illinois bundleflower interseeded into established kleingrass pasture in 1983 in Texas.

\begin{tabular}{lcccc}
\hline \hline & \multicolumn{3}{c}{ Yield $\left(\mathrm{kg} \mathrm{ha}^{-1}\right)$} & $\begin{array}{c}\text { Percent } \\
\text { legume }\end{array}$ \\
\cline { 2 - 5 } & Legume & Grass & Total & \\
\hline Broadcast & & & & 12 \\
$\quad$ Control & 224 & 1672 & 1896 & 5 \\
Mefluidide & $97^{* *}$ & 1669 & 1766 & 20 \\
Paraquat & $368^{* *}$ & 1502 & 1870 & 28 \\
Disk & $673^{* *}$ & 1691 & 2364 & \\
Drill & & & & 10 \\
Control & 181 & 1666 & 1847 & 2 \\
Mefluidide & $42^{* *}$ & 1942 & 1984 & 17 \\
Paraquat & $364^{* *}$ & 1727 & 2091 & 18 \\
Disk & $365^{* *}$ & 1704 & 2069 & 14 \\
MEAN & 289 & 1697 & 1986 & 8 \\
LSD (0.05) & 134 & -1 & - & \\
\hline
\end{tabular}

\footnotetext{
**Significantly different from control within the same sowing method $(P<0.05)$.
}

Table 3. Yield components in 1984 of Illinois bundleflower interseeded into established kleingrass pasture in 1983 in Texas.

\begin{tabular}{|c|c|c|c|c|}
\hline & \multicolumn{3}{|c|}{ Yield $\left(\mathrm{kg} \mathrm{ha}^{-1}\right)$} & \multirow{2}{*}{$\begin{array}{l}\text { Percent } \\
\text { legume }\end{array}$} \\
\hline & Legume & Grass & Total & \\
\hline $\begin{array}{l}\text { Broadcast } \\
\text { Control } \\
\text { Mefluidide } \\
\text { Paraquat } \\
\text { Disk }\end{array}$ & $\begin{array}{c}1103 \\
774 \\
1159 \\
1753^{* *}\end{array}$ & $\begin{array}{l}1714 \\
1728 \\
1659 \\
1741\end{array}$ & $\begin{array}{l}2817 \\
2502 \\
2818 \\
3494^{* *}\end{array}$ & $\begin{array}{l}39 \\
31 \\
41 \\
50\end{array}$ \\
\hline $\begin{array}{l}\text { Drill } \\
\text { Control } \\
\text { Mefluidide } \\
\text { Paraquat } \\
\text { Disk }\end{array}$ & $\begin{array}{c}833 \\
322 \\
1419^{* *} \\
1006^{*}\end{array}$ & $\begin{array}{l}1796 \\
1962 \\
1803 \\
1720\end{array}$ & $\begin{array}{l}2629 \\
2284 \\
3222 * * \\
2726\end{array}$ & $\begin{array}{l}32 \\
14 \\
44 \\
37\end{array}$ \\
\hline $\begin{array}{l}\text { Mean } \\
\operatorname{LSD}(0.05)\end{array}$ & $\begin{array}{r}1046 \\
207\end{array}$ & $\begin{array}{l}1765 \\
--\end{array}$ & $\begin{array}{r}2811 \\
443\end{array}$ & 10 \\
\hline
\end{tabular}

"Significantly different from control within same sowing method $(P<0.05)$ * Significantly different from control within the same sowing method $(P<0.01)$

the 4 years of the experiment.

\section{Yield and Sward Composition}

Legume yield followed the same trend as legume density. The yield of the disked and broadcast treatment combination was greater than that of any other treatment combination in both 1983 and 1984 (Tables 2 and 3). The mefluidide treatment resulted in lower yields in 1983 and 1984 than the control plots which received no grass suppression treatment. The paraquat and disk treatments resulted in higher legume yield than the control in 1983 and 1984 (Tables 2 and 3). Legume yield was very low in the establishment year, averaging $289 \mathrm{~kg} \mathrm{ha}^{-1}$, with the seedling plants averaging only $3.3 \mathrm{gm}$ plant ${ }^{-1}$. Similar values (ca. 6 gm plant $^{-1}$ ) have been reported for Illinois bundleflower seedlings interseeded into bermudagrass (Skousen and Call 1987). Both legume yield and weight per plant increased dramatically in the second year (Table 3). The seedling plants in 1984 were observed to have similar dry weights as those of the first year. The substantial increase of legume yield and plant weight in the second year of the study was due to the greater production potential of the perennial Illinois bundleflower plants. Since perennial legume density in 1984 largely reflected the legume seedling density in the establishment year and perennial legumes were the major contributor to legume yield, trends in legume yield were similar in 1983 and 1984 (Tables 1, 2, and 3). Legume yield increased as perennial legume density increased. Average legume yield rose from $1,046 \mathrm{~kg} \mathrm{ha}^{-1}$ in 1984 to 1,306 and $2,880 \mathrm{~kg} \mathrm{ha}^{-1}$ in 1985 and 1986 as average perennial legume density rose from 3.1 to 7.0 and 8.7 over the same time period.

Grass yield was not affected by grass suppression treatment or legume competition in 1983 or 1984 . However, in 1985 and 1986 grass yield from interseeded plots was significantly lower than

Table 4. Summary of yield components averaged across all establishment treatments for Illinois bundleflower interseeded into an established kleingrass pasture in Texas.

\begin{tabular}{|c|c|c|c|c|}
\hline & \multicolumn{3}{|c|}{ Interseeded Plots } & \multirow{2}{*}{$\begin{array}{l}\text { Grass } \\
\text { alone }\end{array}$} \\
\hline & Legume & Grass & Total & \\
\hline \multirow{5}{*}{$\begin{array}{l}1983 \\
1984 \\
1985 \\
1986\end{array}$} & & $-(\mathrm{K}$ & & \\
\hline & 289 & 1697 & 1986 & 1892 \\
\hline & 1046 & 1765 & $2811^{*}$ & 1963 \\
\hline & 1306 & $1205^{*}$ & $2511^{*}$ & 1708 \\
\hline & 2880 & $2020^{*}$ & $4900^{*}$ & 3363 \\
\hline
\end{tabular}

"Significantly different from grass yield of non-interseeded plots $(P<0.05)$. 
noninterseeded plots (Table 4). It appears that under the conditions of this study (i.e., no added nitrogen) Illinois bundleflower can compete effectively when interseeded into a perennial warmseason grass pasture. This is further demonstrated by observing sward composition over the length of the study. The legume component comprised only $14 \%$ of the sward in the first year after seeding but increased to 37,52 , and $59 \%$ in 1984,1985 , and 1986 , respectively.

Although kleingrass yield decreased as Illinois bundleflower became a more dominant component of the sward, interseeding generally resulted in greater total yields. Due to low legume yields in the establishment year, there was no difference in total yield between interseeded and noninterseeded plots in 1983. However, in 1984,1985 , and 1986 , interseeded plots yielded 43,47 , and $45 \%$ more than noninterseeded plots, respectively (Table 4).

Sowing method and grass suppression treatments affected total yield in 1984 . By the 1985 and 1986 harvests, the density of Illinois bundleflower was no longer affected by establishment treatments.

\section{Literature Cited}

Anonymous. 1984. Sabine Illinois bundleflower-a warm-season perennial legume. Texas Agr. Exp. Sta. L-21224. Texas A \& M Univ., College Station.

Campbell, M.A., and F.G. Swain. 1973. Factors causing losses during the establishment of surface-sown pastures. J. Range Manage. 26:355-359.

Cook, S.J., and G.R. Dolby. 1981. Establishment of buffel grass, green panic, and siratro from seed broadcast into a speargrass pasture in southern Queensland. Aust. J. Agr. Res. 32:749-759.

Cullen, N.A. 1966. Pasture establishment on unplowable hill country in New Zealand. p. 851-855. In: Proc. X Inter. Grassl. Congr. Univ. of Helsinki, Helsinki.

Elkins, D.M., and D.L. Suttner. 1974. Chemical regulation of grass growth. I. Field and greenhouse studies with tall fescue. Agron. J. 66:487-491.

Gerrish, J.R., and C.T. Dougherty. 1983. Tall fescue sward response to mefluidide and nitrogen. Agron. J. 75:895-898.

Groya, F.L., and C.C. Shexffer. 1981. Establishment of sod-seeded alfalfa at various levels of soil moisture and grass competition. Agron. J. 73:560-565.
Holt, E.C. 1984. Seed weight and seedling vigor in Illinois bundleflower. p. 160-168. In: Forage Research in Texas. Texas Agr. Exp. Sta. CPR-4253. Texas A \& M Univ., College Station.

Holt, E.C., and L.D. Allison. 1981. Evaluation of tropical and warmseason legumes. p. 79-87. In: Forage Research in Texas. Texas Agr. Exp. Sta. Dep. Tech. Rep. 81-12. Texas A \& M Univ., College Station.

Holt, E.C., M. Haferkamp, and L.D. Allison. 1980. The growth and quality of selected legumes and grasses in a $750 \mathrm{~mm}$ rainfall area. p. 97-99. In: Forage Research in Texas. Dep. Tech. Rep. 80-6. Texas A \& M Univ., College Station.

Kunelius, H.T., A.J. Campbell, K.B. McRac, and J. Ivany. 1982. Effects of vegetation suppression and drilling techniques on the establishment and growth of sod-seeded alfalfa and birdsfoot trefoil in grass dominant swards. Can. J. Plant. Sci. 62:667-675.

Latting, June. 1961. The biology of Desmanthus illinoensis. Ecology. 42:487-493.

McWilliam, J.R., and P.M. Dowling. 1970. Factors influencing the germination and establishment of seed on the soil surface. p. 573-583. In: Proc. XI Int. Grassl. Congr. Univ. Queensland Press, Brisbane.

Mott, J.J., G.M. Makeon, and C.J. Moore. 1976. Effects of seed bed conditions on the germination of four Stylosanthes species in the Northem Territory. Aust. J. Agr. Res. 27:811-823.

Olsen, F.J., J.H. Jones, and J.J. Patterson. 1981. Sod-seeding forage legumes in a tall fescue sward. Agron. J. 73:1032-1036.

Siewerdt, Lotar, and E.C. Holt. 1974. Yield components and quality of siratro-kleingrass association. Agron. J. 66:65-67.

Skousen, J.G., and C.A. Call. 1987. Sod-seeding to modify coastal bermudagrass on reclaimed lignite overburden in Texas. Reclam. and Reveg. Res. 6:163-176.

Snedecor, G.W., and W.G. Cochran, 1980. Statistical methods. Iowa State University Press, Ames.

Taylor, T.H., E.M. Smith, and W.C. Templeton. 1969. Use of minimum tillage and herbicide for establishing legumes in Kentucky bluegrass ( $P$ oa pratensis L.) swards. Agron. J. 61:761-766.

Wasser, C.H. 1982. Illinois bundleflower. p. 500-503. In: C.H. Wasser (ed.) Ecology and culture of selected species useful in revegetating disturbed lands in the West. U.S. Dep. Int., Fish Wildl. Serv., Washington, D.C.

Watschke, T.L. 1979. Effects of mefluidide and MH on tall fescue. Northeastern Weed Sci. Soc. 33:320-323.

Welch, T.G., and M.R. Haferkamp. 1980. Seeding rangeland. Texas Agr. Ext. Serv. B-1379. Texas A \& M Univ., College Station.

Whiteman, P.C. 1980. Tropical pasture science. Oxford University Press, New York. 